\title{
PPAR-alpha and PPAR-beta expression changes in the hippocampus of rats undergoing global cerebral ischemia/reperfusion due to PPAR-gamma status
}

Ying Luo', Qin He², Ge Kuang ${ }^{1}$, Qingsong Jiang ${ }^{1}$ and Junqing Yang ${ }^{1 *}$

\begin{abstract}
Background: Peroxisome proliferator-activated receptors (PPARs, including alpha, beta and gamma subtypes) and their agonists have a protective role in treatment of central nervous system (CNS) diseases. The present study was designed to investigate the expression changes of PPAR-alpha, -beta,-gamma and NF-kappa B in the hippocampus of rats with global cerebral ischemia/reperfusion injury (GCIRI) after treatment with agonists or antagonists of PPAR-gamma.
\end{abstract}

Methods: A rat GCIRI model was established by occlusion of bilateral common carotid arteries and cervical vena retransfusion. GW9662 $(5 \mathrm{\mu g})$, a selective PPAR- gamma antagonist, was intraventricularly injected at $0.5 \mathrm{~h}$ before GCIR; Rosiglitazone $(0.8,2.4$ and $7.2 \mathrm{mg} / \mathrm{kg})$, a selective PPAR- gamma agonist, was injected intraperitoneally at $1 \mathrm{~h}$ before GCIRI. The expression changes of PPAR-alpha, -beta and -gamma at mRNA and protein levels were detected by RT-PCR and western blotting. The changes of spatial learning and memory (SLM) functions were assessed by using a Morris water maze; the pathohistological changes of hippocampal neurons were evaluated by hematoxylin-eosin (HE) staining; the contents of IL-1, IL-6, IL-10 and TNF-alpha, and the NF- kappa B expression were measured by enzyme-linked immunosorbent assay (ELISA) and immunohistochemical staining. The superoxide dismutase (SOD) activity and malondialdehyde (MDA) content were also detected.

Results: The SLM function and hippocampal neurons were significantly impaired after the occurrence of GCIRI. The MDA, IL-1, IL-6, IL-10, TNF-alpha content and expression of PPARs increased significantly, but the SOD activity and NF-kappa B expression were weakened in the hippocampus. Rosiglitazone treatment significantly protected rats from SLM function impairment and neuron death, and resulted in higher expressions of SOD activity and NF-kappa B, but lower contents of MDA and inflammatory factors. After treatment with rosiglitazone or GW9662, no significant change in PPAR-alpha or -beta expression was detected.

Conclusions: Rosiglitazone, a PPAR-gamma agonist, plays a protective role in hippocampal neuron damage of GCIRI rats by inhibiting the oxidative stress response and inflammation. The activation or antagonism of PPAR-gamma did not affect the expression of PPAR-alpha or -beta, indicating that the three subtypes of PPARs act in independent pathways in the CNS.

Keyword: Global cerebral ischemia-reperfusion injury, Hippocampus, Peroxisome proliferator-activated receptors

\footnotetext{
* Correspondence: cajqyang2004@aliyun.com

'Department of Pharmacology, Chongqing Key Laboratory of Biochemistry and Molecular Pharmacology, Chongqing Medical University, Medical

College Rd. No 1, Chongqing 400016, P. R. China

Full list of author information is available at the end of the article
} 


\section{Background}

Peroxisome proliferator-activated receptors (PPARs), which belong to the nuclear receptor family of ligand-activated transcription factors, were originally described as gene regulators of various metabolic pathways, such as metabolism, adipogenesis, trophoblast differentiation, cell migration and inflammation control [1-6]. PPAR- $\alpha$ is mainly expressed in brown adipose tissues, the liver, muscles and the kidney; it is mainly involved in regulating lipid metabolism, insulin sensitivity and glucose homeostasis $[7,8]$. PPAR- $\beta$ is expressed all over the body and participates in embryonic development, implantation, bone formation and lipid metabolism $[9,10]$. PPAR- $\gamma$ is mainly expressed in adipose tissues, colonic epithelia, macrophages, the liver, the spleen and the kidney; it plays an important role in insulin sensitivity, cell cycle regulation and cell differentiation [11]. In the past decade, tremendous progress has been made towards understanding the physiological roles of PPARs in the occurrence and development of many human diseases, including diabetes, obesity, atherosclerosis, hypertension and cancer.

Global cerebral ischemia/reperfusion injury (GCIRI) occurs in patients who are successfully resuscitated from various clinical conditions such as cardiac arrest, asphyxia and shock, which are frequently accompanied by inflammation and can lead to serious neuronal injury, and further to neurodegeneration and learning and memory impairment [12]. Proinflammatory cytokines, such as interleukin (IL)-1 $\beta$, IL-6 and tissue necrosis factor (TNF)- $\alpha$, have been implicated as important mediators of injury following cerebral ischemia [13] and contribute to pathogenesis, exacerbating brain tissue damage following ischemia/reperfusion (I/R) injury [14].

In addition to regulating metabolism, activation of PPARs results in anti-inflammation and antioxidative effects [15]. Intriguingly, recent reports show that activation of PPARs is helpful in regulating neuronal death in patients with ischemic brain injury and neurodegenerative diseases [16-19]. The expression level of PPAR- $\alpha$ genes in the hippocampus and the improvement of cognitive performance were increased by the reduction of the $n-6: n-3$ fatty acid ratio [20]. The effects of palmitoylethanolamide (PEA) on astrocyte activation and neuronal loss and subsequently the improved neuronal survival in models of amyloid- $\beta(A \beta)$ neurotoxicity are dependent on the expression of PPAR- $\alpha$ [21]. Genetic ablation of PPAR- $\alpha$ in mice exacerbated the systemic toxicity of 1-methy 1-4 -phenyl1,2,3,6-tetrahyropyridine (MPTP), while PEA-induced neuroprotection was partially PPAR- $\alpha$-dependent [22]. The central administration of PPAR- $\delta / \beta$ agonists significantly and dose-dependently attenuated the ischemic brain damage after reperfusion in rats [23]. GW0742 as an agonist of PPAR- $\delta / \beta$ exerts significant neuroprotective effects in rats with GCIRI via PPAR- $\delta / \beta$ activation and its antiinflammation effect [24].

PPAR- $\gamma$ is the focus among the three PPAR subtypes in terms of their neuroprotective effects. In animal models of neurological and cardiovascular diseases, rosiglitazone prevents neuronal cell death and reduced infarct volume after ischemia and reperfusion [25]. Thiazolidinediones (an agonists of PPAR- $\gamma$ ) modulate the maturation and differentiation of microglia and astrocytes, and inhibit the production of nitric oxide $(\mathrm{NO})$, pro-inflammatory cytokines TNF- $\alpha$, IL- $1 \beta$ and IL- 6 , and chemokine MCP-1 from microglia and astrocytes [26]. In addition, pioglitazone increases the cerebral level of $\mathrm{Cu}$ - $\mathrm{Zn}$ superoxide dismutase $(\mathrm{Cu}-\mathrm{Zn} \mathrm{SOD})$ and significantly reduces the infarct size induced by transient but not permanent MCAO [27]. Intraventricular administration of pioglitazone $24 \mathrm{~h}$ before MCAO significantly reduces the expressions of IL-1, COX-2 and inducible nitric-oxide synthase (iNOS) induced by inflammation [28]. These results demonstrate that PPAR- $\gamma$ agonists have protective effects on focal cerebral ischaemia-reperfusion injury (IRI), and that the action mechanisms include inhibition of inflammatory reaction and oxidative stress. However, those studies focus on the neuroprotective effect of PPAR- $\gamma$ in focal ischemia models, but not on the expression and effect of PPAR- $\gamma$ in the GCIRI model.

Four major domains have been identified in PPARs: A/B, C, D and E/F. Domain C is comprised of about 70 amino acids and encodes the DNA-binding domain (DBD). Domain E, which is the ligand-binding domain (LBD), is responsible for ligand specificity and activation of PPAR binding to the peroxisome proliferator response element (PPRE) with resultant modulation of gene expression. In humans, there is about an $86 \%$ identity between PPAR- $\alpha$ and $-\beta$ and $83 \%$ identity between PPAR- $\alpha$ and $-\gamma 1$ in DBD, and about a $70 \%$ identity between PPAR- $\alpha$ and $-\beta$ and $68 \%$ identity between PPAR- $\alpha$ and $-\gamma 1$ in LBD [10], which are similar in humans. However, the sequences of PPARs have high identity in rats: about an $86 \%$ identity between PPAR- $\alpha$ and $-\beta$ and $83 \%$ identity between PPAR$\alpha$ and $-\gamma$ in DBD, and about a $66 \%$ identity between PPAR- $\alpha$ and $-\beta$ and $62 \%$ identity between PPAR- $\alpha$ and $-\gamma$ in LBD. Under such percentages of identity in the structure among those three isotypes, it has not been characterized whether the expression change of PPAR- $\gamma$ will affect those of the other subtypes, or whether activation or inhibiton of PPAR- $\gamma$ will affect the expressions of the other subtypes.

The objectives of the present study are to investigate whether the PPAR- $\gamma$ agonist exerts beneficial action on the memory and learning function by anti-oxidant and inhibits inflammatory reaction: investigate the expression of PPARs in the hippocampus of GCIRI rats, to evaluate the changes of PPAR- $\alpha$ and $-\beta$ expressions due to agonism 
or antagonism of PPAR- $\gamma$, and to test whether the three PPAR isotypes are acting in independent pathways in the CNS. The results will provide a basis for combination of PPARs to prevent GCIRI in the clinical setting.

\section{Method}

\section{Animals and experimental design}

Experiments were approved by the Animal Laboratory Administrative Center and the Institutional Ethics Committee at Chongqing Medical University. 84 Sprague-Dawley (SD) male rats (200-250 g, from the Laboratory Animal Center of Chongqing Medical University) were subjected to bilateral carotid artery occlusion. Prior to the artery occlusion, the rats were randomly allocated to the following groups:

1. Sham group: The animals were subjected to the same surgical procedures as other groups but the common carotid arteries were not occluded $(n=12)$.

2. Ischemia/Reperfusion (I/R) group: The rats received $\operatorname{GCIR}(\mathrm{n}=12)$.

3. $0.8 \mathrm{mg} / \mathrm{kg}$ rosiglitazone group: Identical to ischemia model group, except for receiving rosiglitazone (a kind gift from Prof. Xi-He Yan from Department of Medicinal Chemistry of Chongqing Medical University) $0.8 \mathrm{mg} / \mathrm{kg}$ i.p. 1 hour prior to artery occlusion $(\mathrm{n}=12)$.

4. $2.4 \mathrm{mg} / \mathrm{kg}$ rosiglitazone group: Identical to ischemia model group except for receiving rosiglitazone $2.4 \mathrm{mg} / \mathrm{kg}$ i.p. at 1 hour prior to artery occlusion ( $\mathrm{n}=12)$.

5. $7.2 \mathrm{mg} / \mathrm{kg}$ rosiglitazone group: Identical to ischemia model group except for receiving rosiglitazone $7.2 \mathrm{mg} /$ $\mathrm{kg}$ i.p. at 1 hour prior to artery occlusion $(\mathrm{n}=12)$.

6. $7.2 \mathrm{mg} / \mathrm{kg}$ rosiglitazone plus GW9662 group: Identical to ischemia model group except for receiving GW9662 (Alexis, USA) $5 \mu$ g, i.c.v. [29], at $30 \mathrm{~min}$ prior to artery occlusion and rosiglitazone $7.2 \mathrm{mg} / \mathrm{kg}$ i.p. at 1 hour prior to artery occlusion $(n=12)$.

7. GW9662 in sham control group: Identical to sham group except for receiving GW9662 $5 \mu$ g, i.c.v., at 30 min prior to sham surgery $(n=12)$.

\section{GCIRI animal model}

Rats were anesthetized with $4 \%$ chloral hydrate $(40 \mathrm{mg} /$ $100 \mathrm{~g}$ of body weight). A midline incision $(3 \mathrm{~cm})$ was made in the neck to expose the common carotid vein on the right side and the common carotid artery on both sides. A tubing was inserted via the common carotid vein into the right atrium, and $500 \mathrm{U}$ of heparin were infused. About $30 \%$ of the total blood volume was collected. The common carotid artery on both sides were occluded for $20 \mathrm{~min}$ prior to autologous transfusion of the collected blood prior to artery occlusion. The right common carotid vein was ligated and the incision was closed. The sham operation consisted of similar procedures but the common carotid arteries were not occluded $[24,30,31]$. Body temperature of the rats was maintained at $37.5 \pm 0.5^{\circ} \mathrm{C}$ by the use of a heating pad during the period of ischemia and the following $2 \mathrm{~h}$.

\section{SLM tests}

SLMs were tested using a Morris water maze on the seventh day after the artery occlusion for 5 days (i.e., day 8-day 12 post-GCIRI), following a reported method [32]. The training process consisted of two steps. In step 1 (day 1), the rats were placed on the platform for $1 \mathrm{~min}$, and then were made to swim freely to the platform. If the rats did not reach the platform within $3 \mathrm{~min}$, they were guided to the platform manually by the researchers. On days 2-4, the training consisted of four sessions per day. A different entry site was used for each daily session, and the rats were placed underwater to search for the platform. If the rats did not reach the platform within $3 \mathrm{~min}$, they were guided to the platform by the researchers and allowed to stay there for $10 \mathrm{sec}$. The maximum search time was set at $3 \mathrm{~min}$. In step 2 (day 5), the platform was removed, and the rats were placed in the entry site where the last training was performed. The latency was recorded with a maximum of $3 \mathrm{~min}$.

\section{Histopathological and IHC examinatios}

Rats were anesthetized with $4 \%$ chloral hydrate $(40 \mathrm{mg} /$ $100 \mathrm{~g}$ ) prior to perfusion with $4 \%$ paraformaldehyde. The brains were removed and stored in $4 \%$ paraformaldehyde. Brain sections (each $5-\mu \mathrm{m}$ ) were prepared for staining with hematoxylin-eosin (HE). The morphology of hippocampal neurons and changes at the cellular level were observed.

An immunohistochemical method was used to test the expression of the NF- $\mathrm{kB}$ p 65 protein. The sections were obtained from the same paraffin blocks as used for histological evaluation. High pressure antigen retrieval was performed in citrate buffer for 10 min prior to peroxidase quenching with $3 \% \mathrm{H}_{2} \mathrm{O}_{2}$ in phosphate-buffered saline (PBS) for $10 \mathrm{~min}$. The sections were then washed in water and preblocked with normal goat serum for $10 \mathrm{~min}$. Then, slides were incubated with a rabbit polyclonal antibody raised against NF- $\mathrm{kB}$ p65 (1:50, Santa Cruz, CA) [24] overnight at $4{ }^{\circ} \mathrm{C}$. The sections were then incubated with biotinylated secondary antibodies (1:400, BIO-LAB, China) [33] for $20 \mathrm{~min}$. Following a washing step with PBS, the avidin-biotin complex was applied. Finally, the sections were rinsed in PBS, developed with diaminoben-zidine tetrahydrochloride substrate for $3 \mathrm{~min}$ and counterstained with hematoxylin. The Integral Optical Density (IOD) were analyzed by image-pro plus 6.0 software. 


\section{Reverse transcription polymerase chain reaction (RT-PCR) of PPARs MRNA}

Total RNA was extracted from hippocampal tissue using TRIzol reagent (BioFlux). The RT-PCR system included $1 \mu \mathrm{g}$ total RNA, $1 \mu \mathrm{mol} / \mathrm{L}$ oligo(dT), $0.2 \mathrm{mmol} / \mathrm{L}$ dNTPs, 10 U RNase inhibitor and 4 U ReverTra Ace (FSK-100, Toyobo). The reaction consisted of $20 \mathrm{~min}$ at $42^{\circ} \mathrm{C}, 5 \mathrm{~min}$ at $99^{\circ} \mathrm{C}$ and then $5 \mathrm{~min}$ at $4^{\circ} \mathrm{C}$. The primers of PPARs were designed using Primer Premier 5.0 (Premier Biosoft International, Palo Alto, California, USA) on the basis of the rat PPARs cDNA sequence in genebank and synthesized by Sangon Biotech Co., Ltd. (Shanghai, China). The primers of endogenous $\beta$-Actin were purchased from DINGGUO Biotech Incorporated Company (Beijing, China). The primers were: for PPAR- $\alpha$, forward (F): $5^{\prime}-A$ CGATGCTGTCCTCCTTGATG-3', reverse (R): 5'-GCG TCTGACTCGGTCTTCTTG-3'; for PPAR- $\beta$, F: 5 '-GCC GCCCTACAACGAGATCA-3'; R: 5'-CCACCAGCAGTC CGTCTTTGT-3; for PPAR- $\gamma$, F: 5'-CCCTTTACCACG GTTGATTTCTC-3', R: 5'-GCAGGCTCTACTTTGATC GCACT-3'. Primers for $\beta$-actin were purchased from Beijing Dingguo Biotechnology: F: 5'-GTGGGGCGCC CCAGGCACCA-3'; R: 5'-CTTCCTTAATGTCACGCA CGATTTC-3'. Amplification was carried out in $0.2 \mathrm{mmol} / \mathrm{L}$ dNTPs, $2 \mathrm{mmol} / \mathrm{L} \mathrm{MgCl}_{2}, 1 \mu \mathrm{mol} / \mathrm{L}$ of each primer, and 2.5 U Taq DNA polymerase (Promega), and consisted of the following steps: initial denaturation at $94^{\circ} \mathrm{C}$ for $4 \mathrm{~min}$, followed by 35 cycles of $94^{\circ} \mathrm{C}$ for $15 \mathrm{sec}, 53.1^{\circ} \mathrm{C}$ for $15 \mathrm{sec}$ and $72^{\circ} \mathrm{C}$ for $40 \mathrm{sec}$, annealing at $55.2-57^{\circ} \mathrm{C}$ (at 55.2, 57.0 and $53.1^{\circ} \mathrm{C}$ for PPAR- $\alpha, \mathrm{R}-\beta$ and $-\gamma$ respectively for $15 \mathrm{sec}$ ), and a final extension at $72^{\circ} \mathrm{C}$ for $5 \mathrm{~min}$. The amplified products were separated with $2 \%$ agarose gel electrophoresis. The optical density of PPAR- $\gamma$ was determined with Quantity One software (Bio-Rad), and expressed as the ratio against $\beta$-actin.

\section{PPARs western blot}

Hippocampal tissue $(50 \mathrm{mg}$ ) was homogenized in $0.5 \mathrm{ml}$ tissue lysate and centrifugated at $12,000 \mathrm{~g}$ at $4^{\circ} \mathrm{C}$ for $5 \mathrm{~min}$. The supernatant was ( $20 \mu \mathrm{g}$ protein) was subjected to sodium dodecyl sulfate polyacrylamide gel electrophoresis (SDS-PAGE) and electrotransferred to polyvinylidene fluoride (PVDF) membranes. The membranes were blocked in 5\% nonfat milk for 1 hour at room temperature. After washing in phosphate buffer solution (PBS) for 3 times, the membrane was incubated with a rabbit-anti-rat PPAR- $\alpha$ antibody (1:1000; Abcam, England) [30], PPAR- $\beta$ antibody (1:1000; Santa Cruz, CA) [24], PPAR- $\gamma$ antibody (1:1000; Abcam, England ) [30] at room temperature overnight, and then incubated with an anti-rabbit IgG conjugated with horseradish peroxidase (1:1000; Santa Cruz, CA) at $37^{\circ} \mathrm{C}$ for 1 hour. The color reaction was carried out using ECL reagents (Pierce, USA). A Bio-Rad imaging system was used to quantify the PPARs band.

\section{Biochemical analysis of hippocampal tissues}

Hippocampal tissue was homogenized with physiological saline at a ratio of 1:9 (weight/volume) in a glass homogenizer. The homogenate was centrifuged at 3,000 rpm for $10 \mathrm{~min}$, and the supernatant was collected to determine superoxide dismutase (SOD) activity using an SOD reagent (Nanjing Jiancheng Bioengineering Institute, China) and to determine the malondialdehyde (MDA) content using a MDA kit (Nanjing Jiancheng Bioengineering Institute). The levels of inflammatory cytokines (TNF- $\alpha$, IL-1 $\beta$, IL- 6 and IL-10) were measured using ELISA kits (ADI, Stamford, USA).

\section{Statistical analysis}

All data are expressed as mean $\pm \mathrm{SD}$, and analyzed using Statistical Package for the Social Sciences v. 12.0 (SPSS 12.0, SPSS Inc., Chicago, IL, USA). Differences among

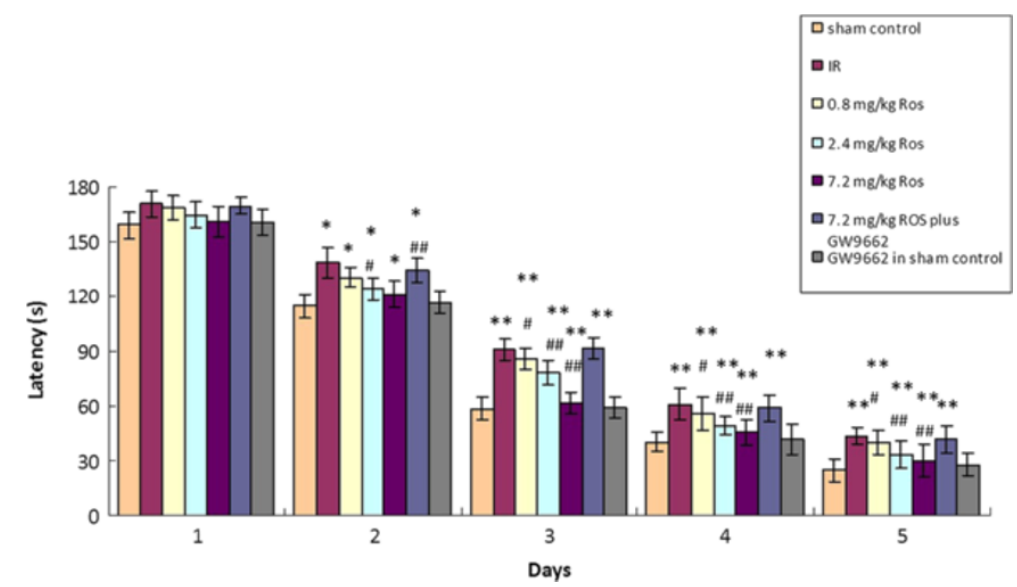

Figure 1 Effects of rosiglitazone on spatial learning and memory function $(\mathbf{n}=\mathbf{1 2}) .{ }^{*}$ and ${ }^{* *}: \mathrm{P}<0.05$ and 0.01 , vs. sham control; ${ }^{\#}$ and \#\#: $P<0.05$ and 0.01 vs. IR. 


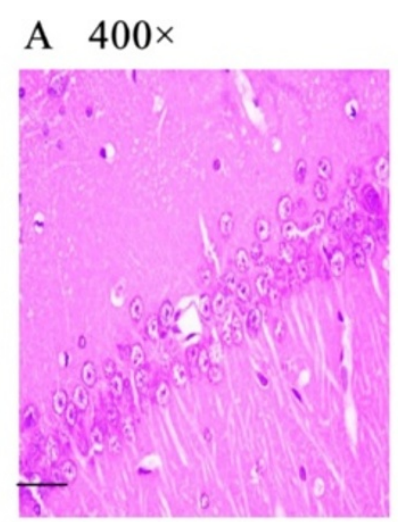

sham control

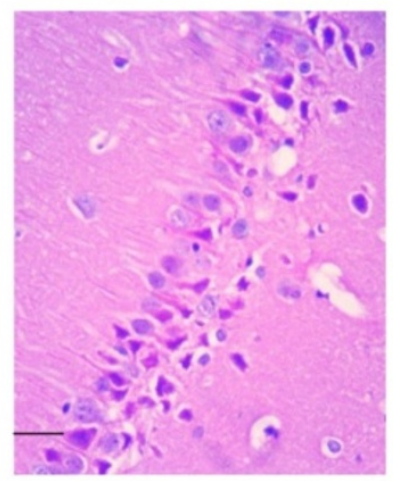

$2.4 \mathrm{mg} / \mathrm{kg}$ ROS

GW9662 in sham control

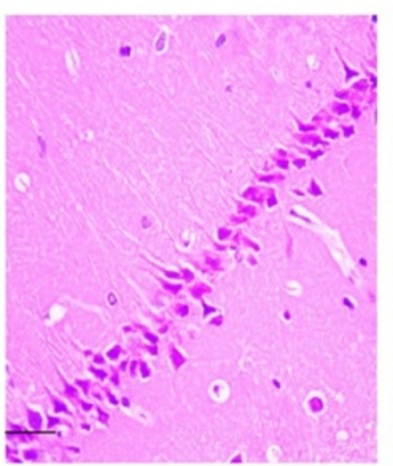

IR

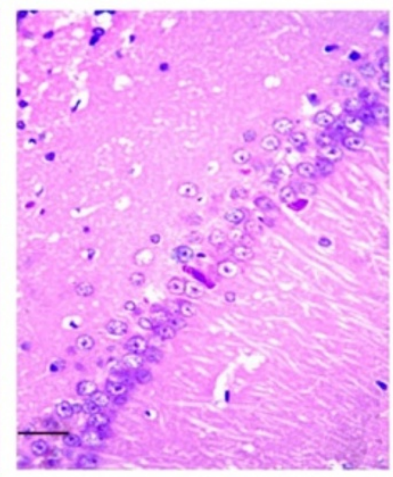

$7.2 \mathrm{mg} / \mathrm{kg}$ ROS

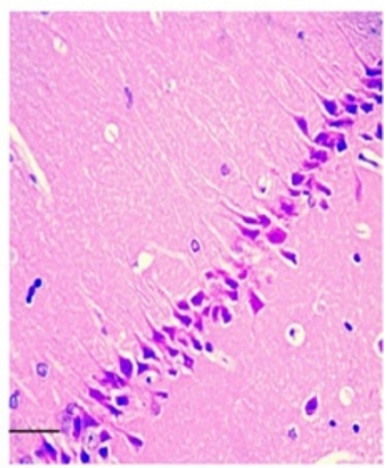

$0.8 \mathrm{mg} / \mathrm{kg}$ ROS

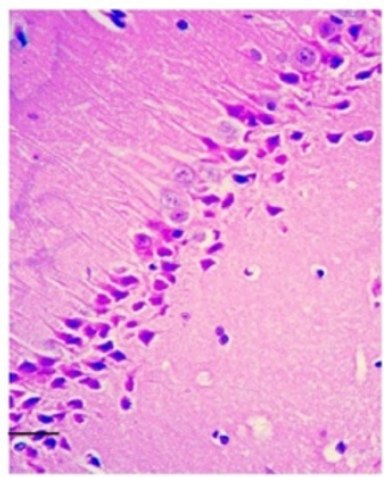

\section{$7.2 \mathrm{mg} / \mathrm{kg}$ ROS plus}

GW9662

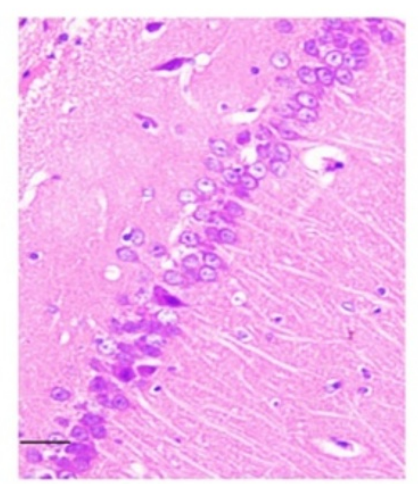

B

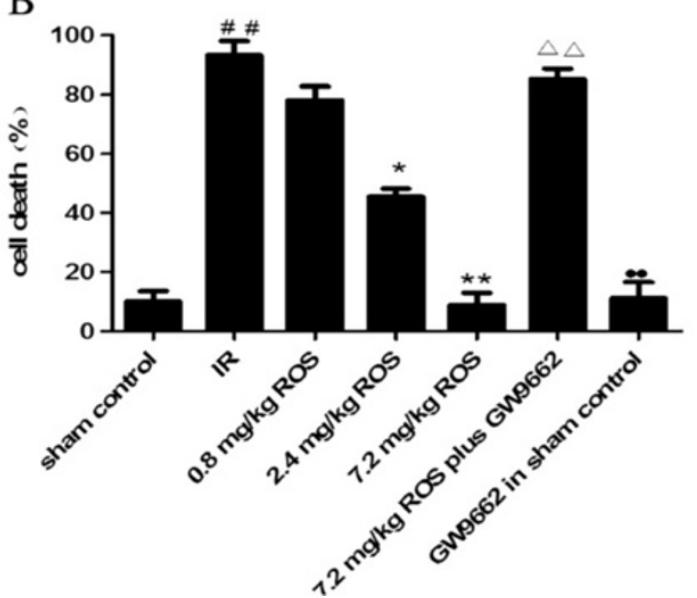

Figure 2 Effects of rosiglitazone on hippocampal neurons in rats with global cerebral IRI (HE stain, $\times \mathbf{4 0 0 ,} \mathbf{n}=\mathbf{3}$ ). A: Representative pictures of H\&E stained CA1 sections on Day 12 post-IRI shown at $400 \times$ magnification. Scale bars $=50 \mu \mathrm{m}$. B: Group data showing the effect of rosiglitazone on the cell death rate. ${ }^{\# \#} \mathrm{P}<0.01$ compared with vehicle sham group; ${ }^{*} \mathrm{P}<0.05{ }^{* *} \mathrm{P}<0.01$ compared with the IR group; ${ }^{\Delta \Delta_{\mathrm{P}}}<0.05$ compared with $7.2 \mathrm{mg} / \mathrm{kg}$ ROS group; $\bullet^{\bullet} \mathrm{P}<0.05$ compared with $7.2 \mathrm{mg} / \mathrm{kg}$ ROS plus GW9662 group.

groups were analyzed by one-way analysis of variance (ANOVA), Student Newman Keuls (SNK) and SNK-q tests. Results were considered significant if the two-tailed $\mathrm{P}$ was $<0.05$.

\section{Results}

Effect of rosiglitazone on learning and memory

Relative to the sham controls, rats with GCIRI had significantly longer platform-seeking time during the training 
phase as well as markedly longer latency on the test day. Rosiglitazone dose-dependently reduced the platformseeking time in the learning and memory phases in rats with GCIRI. GW9662 attenuated the effects of rosiglitazone, but no significant difference was observed between the sham control and the GW9662 in sham control groups (Figure 1).

\section{Histopathological changes}

GCIRI resulted in robust nuclear pyknosis and a reduction in the number of neurons in the hippocampus. In rats pretreated with $7.2 \mathrm{mg} / \mathrm{kg}$ rosiglitazone, hippocampal neurons were clear and intact in structure, and cells were aligned properly. Nuclear pyknosis was evident in the hippocampus of rats pretreated with 0.8 or $2.4 \mathrm{mg} /$ rosiglitazone. GW9662 attenuated effects of rosiglitazone on nuclear pyknosis, but no significant difference was found between the sham control and the GW9662 in sham control groups (Figure 2).

\section{Levels of IL-1 $\beta$, IL- 6 , IL-10 and TNF- $\alpha$}

GCIRI increased the levels of inflammatory cytokines IL-1 $\beta$, IL- 6 and TNF- $\alpha$ in the hippocampus. The IL-10 level was markedly decreased. Rosiglitazone, in a dosedependent manner, attenuated I/R-induced elevation of TNF- $\alpha$, IL- $1 \beta$ and IL- 6 levels and the reduction of IL- 10 . The effects of rosiglitazone were inhibited by GW9662. No significant difference was observed between the sham control and the GW9662 in sham control groups (Table 1).

\section{MDA levels and SOD activity}

Global cerebral I/R resulted in significant increases of MDA content and a decrease in SOD activity in the hippocampus compared to the sham control group. Rosiglitazone attenuated I/R-induced elevation of MDA levels and reduction of SOD activity. The effects of rosiglitazone were inhibited by GW9662, but there was no significant difference between the sham control and the GW9662 in sham control groups (Table 2).
Table 2 Effects of rosiglitozane on MDA content and SOD activity $(n=5)$

\begin{tabular}{lll}
\hline Group & $\begin{array}{l}\text { SOD } \\
(\mathbf{n g} / \mathbf{m l})\end{array}$ & $\begin{array}{l}\text { MDA } \\
(\mathbf{n g} / \mathbf{m l})\end{array}$ \\
\hline sham control & $71.58 \pm 6.23$ & $1.74 \pm 0.14$ \\
IR & $37.24 \pm 5.16^{* *}$ & $2.33 \pm 0.19^{* *}$ \\
$0.8 \mathrm{mg} / \mathrm{kg}$ Ros & $40.37 \pm 4.32^{* *}$ & $2.14 \pm 0.15^{* *}$ \\
$2.4 \mathrm{mg} / \mathrm{kg}$ Ros & $49.37 \pm 7.25^{* \# \#}$ & $1.97 \pm 0.17^{* \# \#}$ \\
$7.2 \mathrm{mg} / \mathrm{kg}$ Ros & $55.47 \pm 9.31^{\# \#}$ & $1.89 \pm 0.21^{\# \#}$ \\
$7.2 \mathrm{mg} / \mathrm{kg}$ Ros plus GW9662 & $35.31 \pm 6.11^{* *}$ & $2.44 \pm 0.17^{* *}$ \\
GW9662 in sham control & $69.43 \pm 4.57$ & $1.83 \pm 0.24$ \\
\hline
\end{tabular}

Datas are expressed as mean $\pm S D(n=5) .{ }^{*}$ and ${ }^{* *}: P<0.05$ and 0.01 , vs. sham control; $^{\#}$ and ${ }^{\# \#: P}<0.05$ and 0.01 vs. IR.

\section{NF-KB p65 expression}

IHC results revealed a significant increase of NF- $\mathrm{kB}$ p65 expression in hippocampal neuronal cytoplasm. Rosiglitazone decreased the expression of NF- $\mathrm{kB}$ p 65 protein in rats subjected to GCIRI. Such an effect was attenuated by GW9662, but there was no significant difference between the sham control and the GW9662 in sham control groups (Figure 3).

\section{PPAR- $\alpha$, PPAR- $\beta$ and PPAR- $\gamma$ mRNA}

GCIRI resulted in significant increases in PPAR- $\alpha$, PPAR- $\beta$ and PPAR $-\gamma$ mRNAs compared with that of the model control group $(\mathrm{p}<0.01)$. Rosiglitazone at $0.8,2.4$ and $7.2 \mathrm{mg} / \mathrm{kg}$ inhibited the increase of the PPAR- $\gamma$ mRNA expression ( $\mathrm{p}<0.05,<0.01$ and $<0.01$, respectively), with an inhibition rate of $10.79 \%, 20.63 \%$ and $32.33 \%$, respectively, in a dose-dependent manner. PPAR- $\alpha$ and PPAR- $\beta$ were not affected. GW9662 had no significant effect on the expression of PPARs in the sham control group (Figure 4).

\section{PPAR- $\alpha$, PPAR- $\beta$ and PPAR- $\gamma$ proteins}

GCIRI resulted in significant increases in the protein levels of PPAR- $\alpha$, PPAR- $\beta$ and PPAR- $\gamma$. Rosiglitazone decreased

Table 1 Effects of rosiglitozane on IL-1b,IL-6,IL-10 and TNF-a content ( $n=5$ )

\begin{tabular}{|c|c|c|c|c|}
\hline Group & $\begin{array}{l}\mathrm{IL}-1 \beta \\
(\mathrm{mg} / \mathrm{ml})\end{array}$ & $\begin{array}{l}\text { IL-6 } \\
\text { (ng/ml) }\end{array}$ & $\begin{array}{l}\text { IL-10 } \\
\text { (ng/ml) }\end{array}$ & $\begin{array}{l}\text { TNF-a } \\
(\mathrm{ng} / \mathrm{ml})\end{array}$ \\
\hline sham control & $218.35 \pm 42.2$ & $6.37 \pm 0.43$ & $3.01 \pm 0.25$ & $2.19 \pm 0.35$ \\
\hline $\mathbb{R}$ & $561.31 \pm 49.98^{* *}$ & $15.83 \pm 1.37^{*}$ & $1.86 \pm 0.15^{* *}$ & $6.36 \pm 1.11^{* *}$ \\
\hline $0.8 \mathrm{mg} / \mathrm{kg}$ Ros & $505.11 \pm 39.28^{* *}$ & $13.27 \pm 0.89^{* *}$ & $2.81 \pm 0.37^{* *}$ & $5.57 \pm 0.43^{* *}$ \\
\hline $2.4 \mathrm{mg} / \mathrm{kg} \operatorname{Ros}$ & $437.71 \pm 51.74^{* * \# \#}$ & $10.27 \pm 0.516^{* * \# \#}$ & $2.37 \pm 0.25^{* * \# \#}$ & $4.23 \pm 0.61^{* * \# \#}$ \\
\hline $7.2 \mathrm{mg} / \mathrm{kg}$ Ros & $390.22 \pm 42.08^{\# \#}$ & $8.05 \pm 0.95^{\# \#}$ & $2.01 \pm 0.31^{\# \#}$ & $3.39 \pm 0.37^{\# \#}$ \\
\hline 7.2 mg/kg Ros plus GW9662 & $572.40 \pm 33.27^{* *}$ & $16.17 \pm 1.12^{* *}$ & $1.95 \pm 0.17^{* *}$ & $6.19 \pm 1.01^{* *}$ \\
\hline GW9662 in sham control & $233.57 \pm 28.33$ & $6.07 \pm 0.33$ & $3.21 \pm 0.35$ & $2.45 \pm 0.22$ \\
\hline
\end{tabular}

Datas are expressed as mean \pm SD $(n=5) .{ }^{*}$ and ${ }^{* *}: P<0.05$ and 0.01 , vs. sham control; ${ }^{\#}$ and ${ }^{\# \#}: \mathrm{P}<0.05$ and 0.01 vs. IR. 


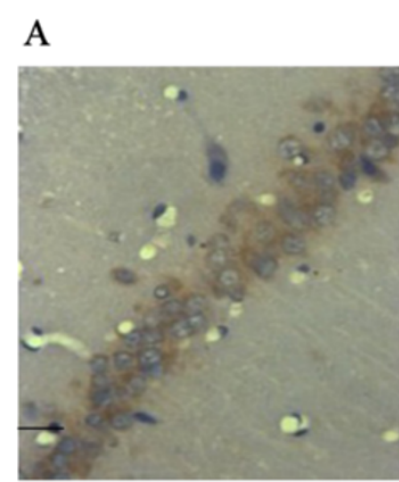

sham control

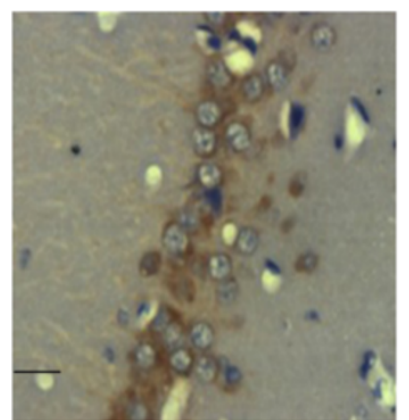

$2.4 \mathrm{mg} / \mathrm{kg}$ ROS

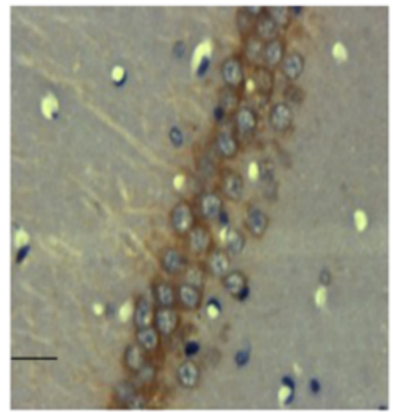

IR

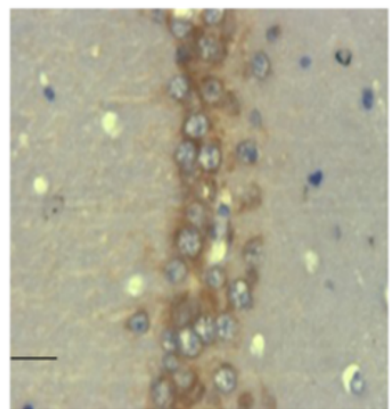

$7.2 \mathrm{mg} / \mathrm{kg}$ ROS

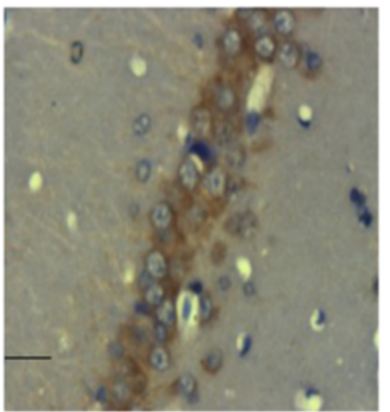

$0.8 \mathrm{mg} / \mathrm{kg}$ ROS

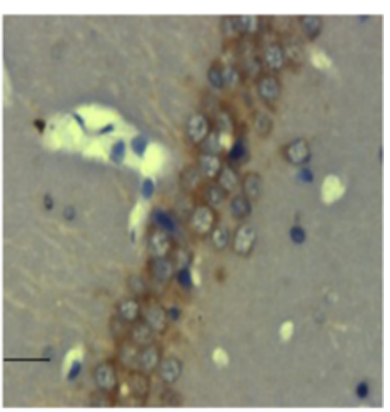

$7.2 \mathrm{mg} / \mathrm{kg}$ ROS plus

GW9662

B

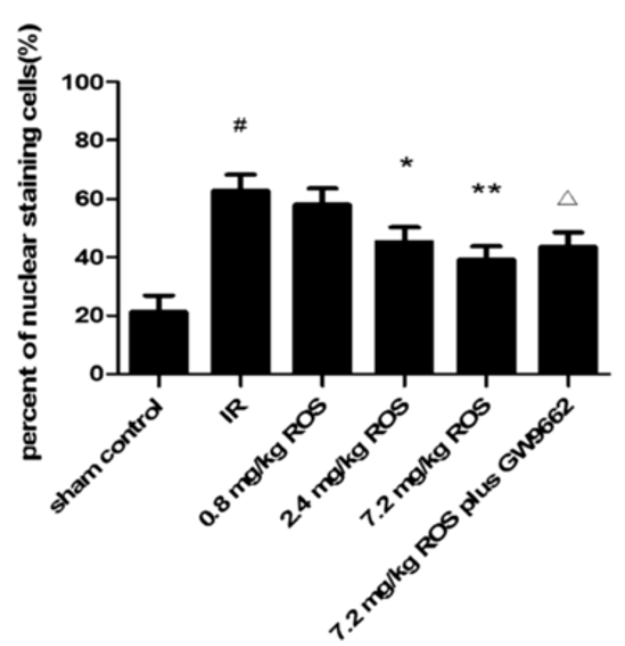

Figure 3 Effects of rosiglitazone on NF-KB expression in hippocampal tissues of rats with global cerebral IRI (HE stain, $\times 400, n=3)$. A: representative images of the hippocampal CA1 region after IRI. (Scale bars $=50 \mu \mathrm{m}$ ). B: Group data showing the effect of rosiglitazone on NFKB expression and translocation. ${ }^{*} \mathrm{P}<0.05$ compared with sham control group; ${ }^{*} \mathrm{P}<0.05{ }^{*} \mathrm{P}<0.01$ compared with the IR group; ${ }^{\Delta} \mathrm{P}<0.05$ compared with $7.2 \mathrm{mg} / \mathrm{kg}$ ROS group.

the PPAR- $\gamma$ protein in the hippocampus of rats with GCIRI in a dose-dependent way. PPAR- $\alpha$ and PPAR- $\beta$ were not affected, and there was no significant difference between the sham control and the GW9662 in sham control groups (Figure 5).

\section{Discussion}

GCIRI occurs in patients who are successfully resuscitated from various clinical conditions such as cardiac arrest, asphyxia and shock, because of the limited therapeutic window (2-3 h after onset of the symptoms), but very 


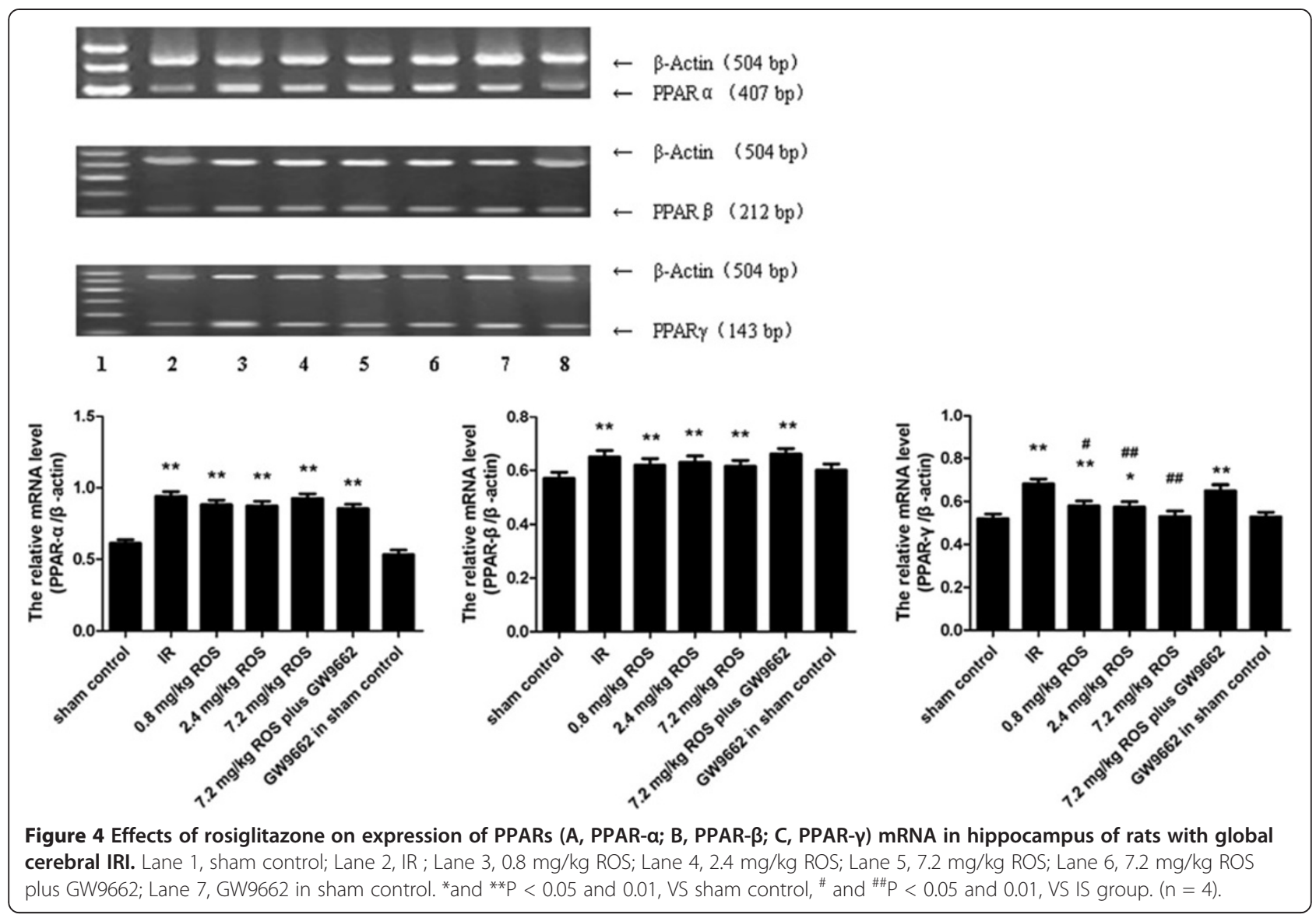

few patients with cardiac arrest receive timely and effective treatment. Therefore, it is of great importance to investigate the molecular mechanisms of such injury caused by ischemic cerebrovascular disease, and thereby to develop effective drugs for treatment.

Our study showed that GCIRI induced inflammation and oxidative stress in the hippocampus of rats. In the hippocampus of rats undergoing GCIRI, the expression of PPARs and the level of NF- $\mathrm{B}$ increased. Rosiglitazone attenuated the damage of hippocampal neurons and improved SLM functions. Such effects were attenuated by the PPAR- $\gamma$ antagonist GW9662. Our results suggest that PPAR- $\gamma$ agonists produce anti-inflammatory action by inhibiting the activation of the NF- $\mathrm{KB}$ signaling pathway and the expressions of inflammatory factors. Intriguingly, neither the agonist nor the antagonist of PPAR- $\gamma$ had any effect on the expression of PPAR- $\alpha$ and PPAR- $\beta$.

Recent reports show that PPARs have a neuroprotective effect on the CNS. Fibrates as PPAR- $\alpha$ ligands have antioxidant and anti-inflammatory effects on GCIRI of female rats, and pretreatment with gemfibrozil prior to $\mathrm{I} / \mathrm{R}$ can modulate inflammatory factors and stimulate the antioxidant defense system [34]. In an experimental model of spinal cord injury in mice, simvastatin can inhibit the severity or level of spinal cord inflammation, neutrophil infiltration, pro-inflammmatory cytokine expression and apoptosis [35]. In addition, PPAR- $\beta$ has become a focus in the field of neuronal damage. Compared with the wild type, the PPAR- $\beta$-null mice exhibit a significantly larger size of infarct in a model of focal cerebral ischemia established by MCAO [36,37]. Preactivation of PPAR- $\beta$ could dose-dependently improve SLM function and cytomorphological change of the hippocampal neurons in the rats with GCIRI [24].

In a previous study on rats, intraventricular administration of pioglitazone at $1 \mathrm{~h}$ before and $24 \mathrm{~h}$ after MCAO separately reduced the infarct area and improved neurological function [38]. Another study demonstrated that in cultured astrocytes and microglia, the expressions of lipopolysaccharide (LPS)-induced IL-6, TNF- $\alpha$, iNOS, and COX- 2 were elevated. The PPAR- $\gamma$ agonists thiadiazolidinones up-regulate the expression of LPS-induced iNOS, and reduce the productions of NO, IL- 6 and TNF- $\alpha$ in a culture. The neuroprotective effects of thiadiazolidinones were abolished by GW9662 [39,40]. Treatment with PPAR- $\gamma$ agonists before MCAO decreases the expressions of ROS and iNOS, decreases lipid peroxidation and reverses glutathione (GSH) exhaustion in the hippocampus 


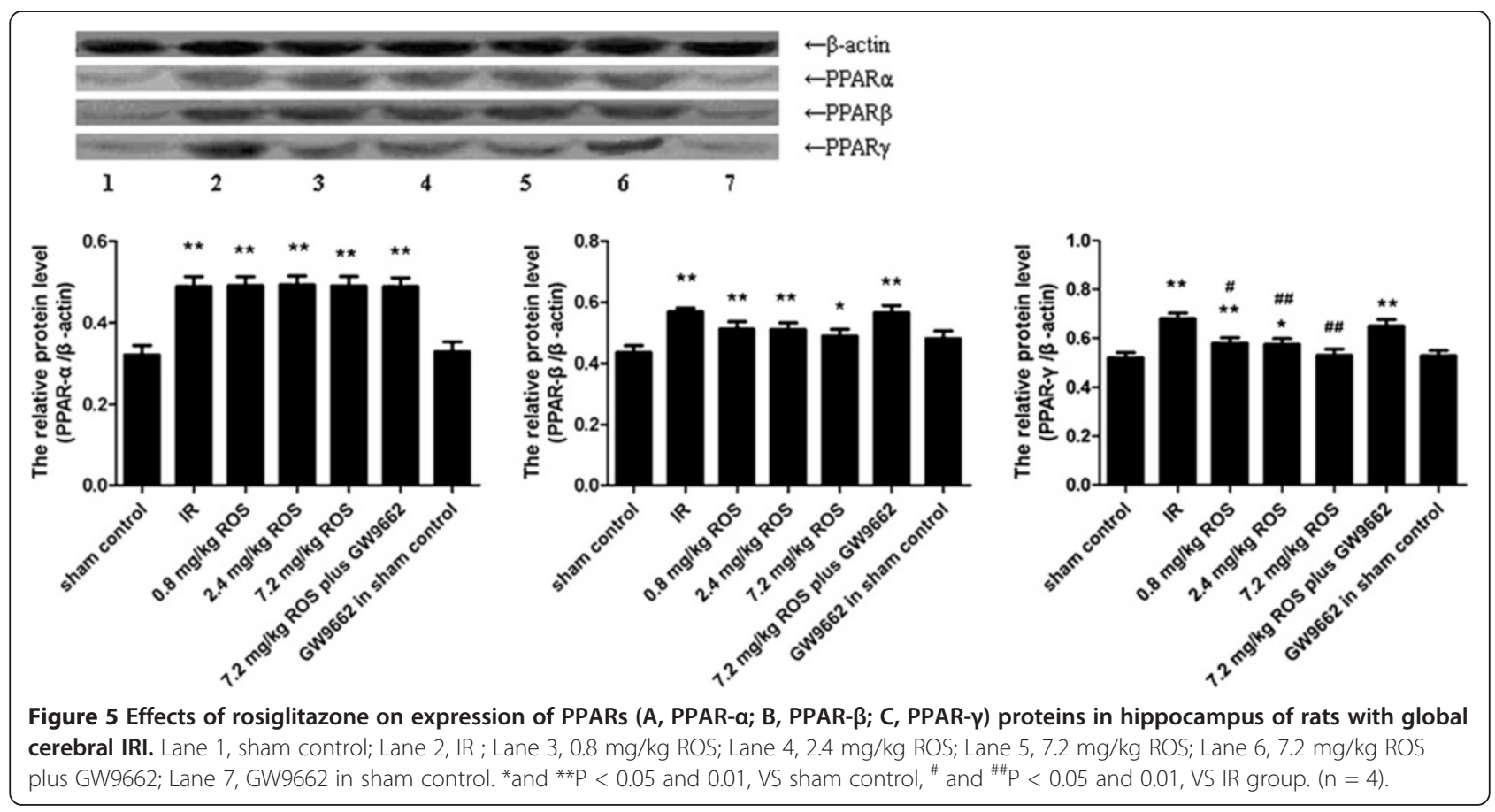

[41]. Pioglitazone inhibits the LPS-induced expression of COX-2 in the primary cortical neurons and prevents neuronal apoptosis induced by oxidative stress [42]. A more recent investigation of the effects of PPAR- $\gamma$ agonists on the NF-kB signaling pathway [43] showed that upon $\mathrm{MCAO}$, the p65 subunit of NF- $\mathrm{kB}$ was transferred from the cytoplasm to the nucleus of the hippocampal neurons. Treatment with pioglitazone subdued the transferrence of the NF- $\kappa B$ p65 subunit to the nucleus. These findings are consistent with our observations and indicate that PPAR $\gamma$ agonists are neuroprotective against GCIRI.

The above results indicate that PPAR- $\alpha,-\beta$ and especially PPAR- $\gamma$ may be important targets for GCIRI research and drug therapy. Although many studies have reported I/R can induce the increased PPAR- $\gamma$ expression $[44,45]$, it is unknown whether the inhibition or activation of the PPAR- $\gamma$ has any effect on the expression of PPAR- $\alpha$ and $-\beta$. This study shows that the expression of PPAR- $\gamma$ in the hippocampus of GCIRI rats increased, and the expressions of PPAR- $\alpha$ and $-\beta$ also increased. Moreover, agonists and antagonists given to PPAR- $\gamma$ had no obvious effect on the expression of PPAR- $\alpha$ or $-\beta$, suggesting that PPAR- $\alpha,-\beta$ and $-\gamma$ act in separate pathways. The intervention of GCIRI by changing the activity or expression of PPAR- $\gamma$ resulted in minimal side effects from the PPAR- $\alpha$ and $-\beta$ expression. Moreover, since PPAR- $\alpha,-\beta$ and $-\gamma$ were three independent pathways, and since the activation or expression of all of them could protect neurons by reducing neuronal inflammation and oxidative stress injury, a superimposed effect may be produced if the three are activated or expressed at the same time. Such hypotheses will be verified in the following experiment to provide new ideas and experimental basis for combined therapy for cerebral ischemic injury by using PPAR- $\alpha,-\beta$ and $-\gamma$ agonists.

\section{Conclusions}

The present study demonstrated that the activation or antagonism of PPAR- $\gamma$ has no effect on the expression of PPAR- $\alpha$ or $-\beta$ in the hippocampus of rats with GCIRI, and the three PPAR isotypes act in three independent pathways in the CNS.

\section{Abbreviations}

$A \beta$ : Amyloid- $\beta$; CNS: Central nervous system; CuZn-SOD: CuZn- superoxide dismutase; DBD: DNA binding domain; DEPC: Diethylpyrocarbonate; EB: Ethidium bromide; ELISA: Enzyme-linked immunosorbent assay; GCIRI: Global cerebral ischemia/reperfusion injury; HE: Hematoxilin and Eosin; IL-1ß: Interleukin-13; IL-6: Interleukin-6; IL-10: Interleukin-10; iNOS: Inductible nitric-oxide synthase; LBD: ligand-binding domain; LPS: lipopolysaccharide; MCAO: Middle cerebral artery occlusion; MDA: Malondialdehyde; MPTP: 1-methyl-4 -phenyl-1,2,3,6-tetrahyropyridine; NF-KB: Nuclear factor-KB; mm: Millimeter; NO: Nitric oxide; PBS: Phosphlate-buffered saline;

PEA: Palmitoylethanolamide; PPARs: Peroxisome proliferator-activated receptors; PPRE: Peroxisomal proliferator response element; RT-PCR: Reverse transcription polymerase chain reaction; SD: Sprague-Dawley; SML: Spatial learning and memory; SOD: Superoxide dismutase; Taq: Taq DNA; TE: Tris-EDTA buffer; TNF-a: Tumor necrosis factor-a; WB: Western blotting.

\section{Competing interest}

The authors declare that they have no competing interest.

\section{Authors' contributions}

Ying collected the data, analyzed and interpreted data, drafted the manuscript. Junqing conceived the idea, designed the study, and participated in writing up and revising the manuscript. Ge, Qin and Qingsong collected the data and assisted data analysis and paper writing. All authors read and approved the final manuscript. 


\section{Acknowledgments}

This work was supported by grants from the Natural Science Foundation of China (Nos. 30672211, 81070972, 81100905) and Chongqing Science Technology Commission of China (CSTC2011AC5203).

\section{Author details}

${ }^{1}$ Department of Pharmacology, Chongqing Key Laboratory of Biochemistry and Molecular Pharmacology, Chongqing Medical University, Medical College Rd. No 1, Chongqing 400016, P. R. China. ${ }^{2}$ The First Affiliated Hospital, Chongqing Medical University, Chongqing 400016, P. R. China.

Received: 20 January 2014 Accepted: 8 June 2014

Published: 16 June 2014

\section{References}

1. Kersten S, Mandard S, Escher P, Gonzalez FJ, Tafuri S, Desvergne B, Wahli W: The peroxisome proliferator-activated receptor alpha regulates amino acid metabolism. FASEB 2001, 15:1971-1978.

2. Nadra K, Anghel SI, Joye E, Tan NS, Basu-Modak S, Trono D, Wahli W, Desvergne B: Differentiation of trophoblast giant cells and their metabolic functions are dependent on peroxisome proliferator-activated receptor beta/delta. Mol Cell Bio/ 2006, 26:3266-3281.

3. Tan NS, Icre G, Montagner A, Bordier-ten-Heggeler B, Wahli W, Michalik L: The nuclear hormone receptor peroxisome proliferator-activated receptor beta/delta potentiates cell chemotactism, polarization, and migration. $\mathrm{Mol}$ Cell Biol 2007, 27:7161-7175.

4. Genolet R, Kersten S, Braissant O, Mandard S, Tan NS, Bucher P, Desvergne B, Michalik L, Wahli W: Promoter rearrangements cause species-specific hepatic regulation of the glyoxylate reductase/hydroxypyruvate reductase gene by the peroxisome proliferator-activated receptor alpha. Biol Chem 2005, 280:24143-24152.

5. Mandard S, Stienstra R, Escher P, Tan NS, Kim I, Gonzalez FJ, Wahli W, Desvergne B, Müller M, Kersten S: Glycogen synthase 2 is a novel target gene of peroxisome proliferator-activated receptors. Cell Mol Life Sci 2007, 64:1145-1157.

6. Chamouton J, Hansmannel F, Bonzo JA, Clémencet MC, Chevillard G, Battle M, Martin P, Pineau T, Duncan S, Gonzalez FJ, Latruffe N, Mandard S, Nicolas-Francès V: The Peroxisomal 3-keto-acyl-CoA thiolase B Gene Expression Is under the Dual Control of PPARa and HNF4a in the Liver. PPAR Res 2010. http://www.hindawi.com/journals/ppar/2010/352957/.

7. Kidani $Y$, Bensinger SJ: Liver $X$ receptor and peroxisome proliferator-activated receptor as integrators of lipid homeostasis and immunity. Immunol Rev 2012, 249:72-83.

8. Monsalve FA, Pyarasani RD, Delgado-Lopez F, Moore-Carrasco R: Peroxisome proliferator-activated receptor targets for the treatment of metabolic diseases. Mediators Inflamm 2013. http://www.hindawi. com/journals/mi/2013/549627/.

9. Peters JM, Gonzalez FJ: Sorting out the functional role(s) of peroxisome proliferator-activated receptor-beta/delta (PPARbeta/delta) in cell proliferation and cancer. Biochim Biophys Acta 2009, 1796:230-341.

10. Guan Y, Breyer MD: Peroxisome proliferators-activated receptors (PPARs): novel therapeutic targets in renal disease. Kidney Int 2001, 60:14-30.

11. Wang Y, Jacome-Sosa MM, Ruth MR, Lu Y, Shen J, Reaney MJ, Scott SL, Dugan ME, Anderson HD, Field CJ, Proctor SD, Vine DF: The intestinal bioavailability of vaccenic acid and activation of peroxisome proliferator-activated receptor- $\alpha$ and $-\gamma$ in a rodent model of dyslipidemia and the metabolic syndrome. Mol Nutr Food Res 2012, 56:1234-1246.

12. Alexandrov AV: Current and future recanalization strategies for acute ischemic stroke. J Intern Med 2010, 267:209-219.

13. Zheng Z, Yenari MA: Post-ischemic inflammation: molecular mechanisms and therapeutic implications. Neurol Res 2004, 26:884-892.

14. Dienz O, Rincon M: The effects of IL-6 on CD4 T cell responses. Clin Immunol 2009, 130:27-33.

15. Camps J, García-Heredia A, Rull A, Alonso-Villaverde C, Aragonès G, Beltrán-Debón $R$, Rodríguez-Gallego E, Joven J: PPARs in Regulation of Paraoxonases: Control of Oxidative Stress and Inflammation Pathways. PPAR Res 2012 http://www.hindawi.com/journals/ppar/2012/616371/.

16. Fong WH, Tsai HD, Chen YC, Wu JS, Lin TN: Anti-apoptotic actions of PPAR-gamma against ischemic stroke. Mol Neurobiol 2010, 41:180-186.
17. Chehaibi K, Hrira MY, Rouis M, Najah M, Jguirim-Souissi I, Nouira S, Slimane MN: Effect of genetic polymorphism $+294 \mathrm{~T} / \mathrm{C}$ in peroxisome proliferator-activated receptor delta on the risk of ischemicstroke in a Tunisian population. Mol Neurosci 2013, 50:360-367.

18. Culman J, Zhao Y, Gohlke P, Herdegen T: PPAR-gamma: therapeutic target for ischemic stroke. Trends Pharmacol Sci 2007, 28:244-249.

19. Heneka MT, Landreth GE: PPARs in the brain. Biochim Biophys Acta 2007, 1771:1031-1045

20. Hajjar T, Meng GY, Rajion MA, Vidyadaran S, Othman F, Farjam AS, Li TA, Ebrahimi M: Omega 3 polyunsaturated fatty acid improves spatial learning and hippocampal perxiomeprolife rator activated receptors (PPARa and PPARy) gene expression in rats. BMC Neurosci 2012, 13:109.

21. Scuderi C, Valenza M, Stecca C, Esposito G, Carratù MR, Steardo L: Palmitoylethanolamide exerts neuroprotective effects in mixed neuroglial cultures and organotypic hippocampal slices via peroxisome proliferator-activated receptor-a. Neuroinflammation 2012, 9:49.

22. Esposito E, Impellizzeri D, Mazzon E, Paterniti I, Cuzzocrea S: Neuroprotective activities of palmitoylethanolamide in an animal model of Parkinson's disease. PLoS One 2012. http://www.plosone.org/article/info \%3Adoi\%2F10.1371\%2Fjournal.pone.0041880.

23. Iwashita A, Muramatsu Y, Yamazaki T, Muramoto M, Kita Y, Yamazaki S, Mihara K, Moriguchi A, Matsuoka N: Neuroprotective efficacy of the peroxisome proliferator-activated receptor $\delta$-selective agonists in vitro and in vivo. Pharmacol Exp Ther 2007, 320:1087-1096.

24. Kuang G, He Q, Zhang Y, Zhuang R, Xiang A, Jiang Q, Luo Y, Yang J: Modulation of Preactivation of PPAR- $\beta$ on Memory and Learning Dysfunction and Inflammatory Response in the Hippocampus in Rats Exposed to Global Cerebral Ischemia/Reperfusion. PPAR Res 2012. http://www.hindawi.com/journals/ppar/2012/209794/.

25. Okami N, Narasimhan P, Yoshioka H, Sakata H, Kim GS, Jung JE, Maier CM, Chan PH: Prevention of JNK phosphorylation as a mechanism for rosiglitazone in neuroprotection after transient cerebral ischemia: activation of dual specificity phosphatase. J Cereb Blood Flow Metab 2013, 33:106-114.

26. Storer PD, Xu J, Chavis J, Drew PD: Peroxisome proliferator-activated receptor-gamma agonists inhibit the activation of microglia and astrocytes: implications for multiple sclerosis. Neuroimmunol 2005, 161:113-122.

27. Shimazu T, Inoue I, Araki N, Asano Y, Sawada M, Furuya D, Nagoya H, Greenberg JH: A peroxisome proliferator-activated receptor-gamma agonist reduces infarct size in transient but not in permanent ischemia. Stroke 2005, 36:353-359.

28. Zhao Y, Patzer A, Herdegen T, Gohlke P, Culman J: Activation of cerebral peroxisome proliferator-activated receptors gamma promotes neuroprotection by attenuation of neuronal cyclooxygenase- 2 overexpression after focal cerebral ischemia in rats. FASEB 2006, 20:1162-1175.

29. Maeda T, Kiguchi N, Fukazawa Y, Yamamoto A, Ozaki M, Kishioka S: Peroxisome proliferator-activated receptor gamma activation relieves expression of behavioral sensitization to methamphetamine in mice. Neuropsychopharmacology 2007, 32:1133-1140.

30. Wang H, Jiang R, He Q, Zhang Y, Zhang Y, Li Y, Zhuang R, Luo Y, Li Y, Wan J, Tang Y, Yu H, Jiang Q, Yang J: Expression Pattern of Peroxisome Proliferator-Activated Receptors in Rat Hippocampus following Cerebral Ischemia and Reperfusion Injury. PPAR Res 2012. http://www.hindawi.com/ journals/ppar/2012/596394/.

31. Yang B, Yu L, Wang J, Zhao L, Hu X, Ji C, Wei Y, Jiang Q, Yang J: Laser Doppler flowmetry optimized the rat model of global cerebral ischemia-reperfusion. Chin J Gerontol 2014, 34:119-122.

32. Zhang J, Yang JQ, He BC, Zhou QX, Yu HR, Tang Y, Liu BZ: Berberine and total base from rhizoma coptis chinensis attenuate brain injury in an aluminum-induced rat model of neurodegenerative disease. Saudi Med J 2009, 30:760-766.

33. Wang $H L$, Xing $Y Q, X u Y X$, Rong F, Lei WF, Zhang WH: The protective effect of lidocaine on septic rats via the inhibition of high mobility group box 1 expression and NF-kB activation. Mediators Inflamm 2013. http://www.hindawi.com/journals/mi/2013/570370/.

34. Mohagheghi F, Khalaj L, Ahmadiani A, Rahmani B: Gemfibrozil pretreatment affecting antioxidant defense system and inflammatory, but not Nrf-2 signaling pathways resulted in female neuroprotection and male neurotoxicity in the rat models of global cerebral ischemia-reperfusion. Neurotox Res 2013, 23:225-237. 
35. Esposito E, Rinaldi B, Mazzon E, Donniacuo M, Impellizzeri D, Paterniti I, Capuano A, Bramanti P, Cuzzocrea S: Anti-inflammatory effect of simvastatin in an experimental model of spinal cord trauma: involvement of PPAR-a. Neuroinflammation 2012. http://www. jneuroinflammation.com/content/9/1/81.

36. Arsenijevic D, de Bilbao F, Plamondon J, Paradis E, Vallet P, Richard D, Langhans W, Giannakopoulos P: Increased infarct size and lack of hyperphagic response after focal cerebral ischemia in peroxisome proliferator-activated receptor $\beta$-deficient mice. Cereb Blood Flow Metab 2006, 26:433-445.

37. Pialat JB, Cho TH, Beuf O, Joye E, Moucharrafie S, Langlois JB, Nemoz C, Janier M, Berthezene Y, Nighoghossian N, Desvergne B, Wiart M: MRI monitoring of focal cerebral ischemia in peroxisome proliferator-activated receptor (PPAR)-deficientmice. NMR Biomed 2007, 20:335-342.

38. Sundararajan S, Gamboa JL, Victor NA, Wanderi EW, Lust WD, Landreth GE: Peroxisome proliferator-activated receptor- $\gamma$ ligands reduce inflammation and infarction size in transient focal ischemia. Neurosci 2005, 130:685-696.

39. Luna-Medina R, Cortes-Canteli M, Alonso M, Santos A, Martínez A, Perez-Castillo A: Regulation of inflammatory response in neural cells in vitro by thiadiazolidinones derivates through peroxisome proliferator-activated receptor activation. Biol Chem 2005, 280:21453-21462.

40. Paola RD, Cuzzocrea S: Peroxisome proliferator-activated receptors ligands and ischemia-reperfusion injury. Naunyn-Schmiedebergs Arch Pharmacol 2007, 375:157-175

41. Bordet R, Ouk T, Petrault O, Gelé P, Gautier S, Laprais M, Deplanque D, Duriez P, Staels B, Fruchart JC, Bastide M: PPAR: a new pharmacological target for neuroprotection in stroke and neurodegenerative diseases. Biochem Soc Trans 2006, 34:1341-1346.

42. Kim EJ, Kwon KJ, Park JY, Lee SH, Moon CH, Baik EJ: Effects of peroxisome proliferator-activated receptor agonists on LPS-induced neuronal death in mixed cortical neurons: associated with iNOS and COX-2. Brain Res 2002, 941:1-10

43. Collino M, Aragno M, Mastrocola R, Gallicchio M, Rosa AC, Dianzani C, Danni $\mathrm{O}$, Thiemermann C, Fantozzi R: Modulation of the oxidative stress and inflammatory response by PPAR- $\gamma$ agonists in the hippocampus of rats exposed to cerebral ischemia/reperfusion. Eur J Pharmacol 2006, 530:70-80.

44. Victor NA, Wanderi EW, Gamboa J, Zhao X, Aronowski J, Deininger K, Lust WD, Landreth GE, Sundararajan S: Altered PPARgamma expression and activation after transient focal ischemia in rats. Eur J Neurosci 2006, 24:1653-1663.

45. Ou Z, Zhao X, Labiche LA, Strong R, Grotta JC, Herrmann O, Aronowski J: Neuronal expression of peroxisome proliferator-activated receptor-gamma (PPARgamma) and 15d-prostaglandin J2-mediated protection of brain after experimental cerebral ischemia in rat. Brain Res 2006, 1096:196-203.

doi:10.1186/1744-9081-10-21

Cite this article as: Luo et al:: PPAR-alpha and PPAR-beta expression changes in the hippocampus of rats undergoing global cerebral ischemia/reperfusion due to PPAR-gamma status. Behavioral and Brain Functions 2014 10:21.

\section{Submit your next manuscript to BioMed Central and take full advantage of:}

- Convenient online submission

- Thorough peer review

- No space constraints or color figure charges

- Immediate publication on acceptance

- Inclusion in PubMed, CAS, Scopus and Google Scholar

- Research which is freely available for redistribution

Submit your manuscript at www.biomedcentral.com/submit
Ciomed Central 